\title{
PENTINGNYA PENGETAHUAN PERAWAT DALAM \\ MELAKSANAKAN PROSES KEPERAWATAN
}

\author{
Novi Pratiwi \\ novipratiwi211@gmail.com
}

\begin{abstract}
Abstrak
Peran perawat sebagai pemberi asuhan merupakan komponen penting yang esensial dalam sistem pemberian pelayanan kesehatan. Untuk menilai kualitas pelayanan keperawatan diperlukan adanya standar praktik keperawatan yang merupakan pedoman bagi perawat dalam melaksanakan asuhan keperawatan yang diwujudkan dalam bentuk proses keperawatan mulai dari pengkajian sampai evaluasi. Dalam hal ini, pengetahuan menjadi salah satu faktor yang erat kaitannya dengan efektifitas penerapan proses keperawatan sebagai bentuk asuhan keperawatan. Dengan adanya pengetahuan perawat yang cukup tentunya akan menjadi lebih mudah dalam melaksanakan proses keperawatan untuk mengarahkan dan memfokuskan dalam upaya meningkatkan mutu asuhan keperawatan.
\end{abstract}

Kata kunci : Perawat, pengetahuan, proses keperawatan

\section{Latar Belakang}

Keperawatan adalah salah satu profesi pelaku pemberi pelayanan kesehatan, memiliki peranan penting dalam menentukan keberhasilan kesehatan secara keseluruhan. Peran perawat sebagai pemberi asuhan merupakan komponen penting yang esensial dalam sistem pemberian pelayanan kesehatan. Kemampuan dan keterampilan perawat yang kuat dalam kepemimpinan dan administratif sangat penting bagi pasien dan keselamatannya serta sistem layanan dan aksesnya.
Perawat sebagai suatu profesi harus dapat mempertahankan dan meningkatkan mutu asuhan keperawatan dengan standar yang ada. Standar memberikan petunjuk kinerja mana yang tidak cocok atau tidak dapat diterima. Standar praktik keperawatan adalah pernyataan tentang apa yang dibutuhkan oleh registered nursed untuk dijalankan sebagai profesi keperawatan. Secara umum standar ini mencerminkan nilai profesi keperawatan dan memperjelas apa yang diharapkan profesi keperawatan dari para anggotanya. 
Untuk menilai kualitas pelayanan keperawatan diperlukan adanya standar praktik keperawatan yang merupakan pedoman bagi perawat dalam melaksanakan asuhan keperawatan yang diwujudkan dalam bentuk proses keperawatan mulai dari pengkajian sampai evaluasi. Dalam hal ini, pengetahuan menjadi salah satu faktor yang erat kaitannya dengan efektifitas penerapan proses keperawatan sebagai bentuk asuhan keperawatan.

Proses keperawatan adalah suatu cara atau metode yang sistematis dalam memberikan asuhan keperawatan yang dilakukan oleh perawat dan bekerjasama dengan pasien untuk mengidentifikasi masalah keperawatan dengan melakukan pengkajian, menentukan diagnosa, merencanakan tindakan yang akan dilakukan, melaksanakan tindakan serta mengevaluasi hasil asuhan keperawatan yang telah diberikan.

Proses keperawatan memfasilitasi perawat untuk berkembang sebagai seorang pemikir yang logis untuk menghasilkan peningkatan respon dan perilaku pasien dalam pemenuhan kebutuhannya serta pentingnya partisipasi pasien dalam keseluruhan proses. Asuhan keperawatan baru dapat dikatakan berhasil dan selesai jika semua tujuan asuhan keperawatan yang telah ditetapkan dalam perencanaan keperawatan telah tercapai.
Berdasarkan uraian latar belakang tersebut perawat dalam melaksanakan asuhan keperawatan harus memperhatikan standar asuhan keperawatan yang ada. Dengan adanya pengetahuan perawat yang cukup tentunya akan menjadi lebih mudah dalam melaksanakan proses keperawatan untuk mengarahkan dan memfokuskan dalam upaya meningkatkan mutu asuhan keperawatan.

\section{Metode}

Metode yang dilakukan dalam penulisan ini adalah metode kepustakaan yaitu dengan melakukan peninjauan dan mengumpulkan data-data yang diperoleh dari buku dan jurnal-jurnal terkini kemudian menganalisis data-data tersebut, mereview dan menentukan bahwa pengetahuan perawat merupakan hal yang penting dalam melaksanakan proses keperawatan. Pengolahan data dilakukan mulai dari menganalisis isi buku dan jurnal hingga kesimpulan dari penulis.

\section{Hasil}

Proses keperawatan didasari oleh teori Orlando Deliberative Nursing Process yang menyatakan bahwa tindakan atau perilaku yang ditunjukkan perawat merupakan hasil pertimbangan berdasarkan kebutuhan pasien. Hal tersebut berarti bahwa perawat profesional melakukan eksplorasi kebutuhan dan masalah atau 
gangguan kebutuhan yang terjadi pada pasien dengan menggunakan persepsi, proses berpikir kritis, penalaran klinis, dan atau perasaan perawat yang berhubungan dengan kebutuhan dasar pasien. Proses keperawatan membantu perawat mendapatkan luaran, mengukur kualitas pelaksanaan asuhan keperawatan dan memudahkan perawat untuk melakukan praktik klinis keperawatan khususnya bagi perawat pemula.

Menurut Florence Nightingale, menyatakan bahwa tindakan dalam asuhan keperawatan harus selalu terpisah dari tindakan medis. Tugas pokok perawat adalah memenuhi kebutuhan dasar manusianya klien dan menata lingkungan keperawatan menjadi lingkungan yang adekuat untuk pemulihan kondisi klien.

Yura and Walsh (1983) menyebutkan bahwa proses keperawatan terdiri atas 4 tahap. Perkembangan selanjutnya pada tahun 1982 melalui National Council of State Boards of Nursing menyatakan bahwa proses keperawatan terdiri atas 5 tahap yaitu pengkajian keperawatan, diagnosa keperawatan, perencanaan keperawatan, implementasi dan evaluasi keperawatan.

Berdasarkan hasil penelitian yang dilakukan oleh Kartin Buheli, menunjukkan sebagian besar perawat $(80,4$ \%) melakukan pengkajian keperawatan dengan baik dan 19,6\% perawat yang masih kurang dalam melakukan pengkajian keperawatan. Untuk diagnosa keperawatan terdapat $60,8 \%$ yang sudah melakukan diagnosa keperawatan dengan baik dan $39,2 \%$ perawat yang masih kurang dalam melakukan diagnosa keperawatan. Dalam melakukan perencanaan keperawatan terdapat $74,5 \%$ perawat yang sudah melaksanakan perencanaan keperawatan dengan cukup dan 25,5 \% yang masih kurang dalam melaksanakan perencanaan keperawatan. Untuk implementasi keperawatan terdapat $74,5 \%$ perawat yang sudah melaksanakan implementasi keperawatan dengan baik dan 25,5\% yang masih kurang dalam melaksanakan implementasi keperawatan. Sedangkan untuk evaluasi keperawatan terdapat 60,8 $\%$ perawat yang sudah melaksanakan evaluasi keperawatan dengan cukup dan $39,2 \%$ yang masih kurang dalam melaksanakan evaluasi keperawatan.

Berdasarkan penelitian tersebut, masih cukup banyak perawat yang kurang dalam melaksanakan proses keperawatan. Maka untuk mengatasi hal tersebut, pengetahuan dan pengalaman yang cukup sangatlah dibutuhkan dalam melaksanakan proses keperawatan untuk mengarahkan dan memfokuskan dalam upaya meningkatkan mutu asuhan keperawatan.

\section{Pembahasan}

Proses keperawatan adalah suatu cara atau metode yang sistematis dalam 
memberikan asuhan keperawatan yang dilakukan oleh perawat dan bekerjasama dengan pasien (induvidu, keluarga, masyarakat) yang bertujuan untuk mengidentifikasi masalah keperawatan dengan melakukan pengkajian, menentukan diagnosa, merencanakan tindakan yang akan dilakukan, melaksanakan tindakan serta mengevaluasi hasil asuhan keperawatan yang telah diberikan dengan berfokus pada pasien, berorientasi pada tujuan yang telah ditetapkan bersama.

Tujuan umum dari proses keperawatan adalah peningkatan kualitas asuhan keperawatan. Adanya proses keperawatan akan menciptakan pelayanan asuhan keperawatan yang berkualitas dengan indikator teratasinya semua masalah yang terkait dengan kebutuhan dasar manusianya klien. Adapun tujuan khususnya adalah sebagai berikut.

1. Teridentifikasinya masalah-masalah terkait kebutuhan dasar manusianya klien.

2. Dapat menentukan diagnosa keperawatan.

3. Tersusunnya perencanaan keperawatan yang tepat untuk mengatasi diagnosa keperawatan.

4. Terlaksananya tindakan-tindakan keperawatan secara tepat dan terencana.

5. Diketahuinya perkembangan klien.
6. Dapat ditentukannya tingkat keberhasilan asuhan keperawatan.

Adapun sifat-sifat dari proses keperawatan adalah sebagai berikut:

1. Terbuka dan fleksibel.

Proses keperawatan menganut sistem terbuka. Jika sewaktu-waktu terjadi perubahan respon klien maka akan memberikan perubahan terhadap diagnosa, rencana dan tindakan yang akan perawat berikan. Fleksibel karena semua rencana yang telah perawat susun tidak serta merta harus dilaksanakan seluruhnya, tetapi harus melihat perubahan dan perkembangan kondisi klien.

2. Dilakukan melalui pendekatan individual.

Terkait masalah yang dihadapi klien, ada banyak hal yang bersifat individual dan merupakan privasi klien. Sehingga tidak kepada semua perawat diberikan kepercayaan oleh klien, atau tidak semua data (yang sehubungan dengan masalah keperawatan) akan disampaikan oleh klien kepada perawat. Pada situasi seperti ini maka dibutuhkan suatu pendekatan yang individual kepada klien dan perawat harus mampu membina hubungan saling percaya dengan klien.

3. Penanganan masalah yang terencana.

Setelah masalah keperawatan ditemukan, yang ditunjang oleh datadata senjang yang merupakan 
karakteristik dari masalah. Selanjutnya perawat akan menyusun perencanaan yang berlandaskan kepada ilmu keperawatan yang kokoh. Semua perencanaan yang disusun berdasarkan konsep keilmuan dan profesionalisme seorang perawat.

4. Mempunyai arah dan tujuan

Perencanaan yang perawat susun mempunyai arah dan tujuan yang akan dicapai dalam batasan waktu tertentu.

5. Merupakan siklus yang saling berhubungan.

Setiap tahap saling berhubungan dan tidak dapat dipisah-pisahkan. Pengkajian menjadi tahap yang paling mendasar. Jika pengkajian perawat gagal dalam artian tidak memperoleh data yang tepat dan akurat, maka perawat akan kesulitan dalam mengenali masalah dan menimbulkan kesalahan dalam menyusun diagnosa keperawatan. Jika diagnosanya sulit dikenali atau salah menegakkan diagnosa keperawatan, maka perawat akan mengalami kesalahan selama penyusunan perencanaan.

6. Terdapat validasi data dan pembuktian masalah

Selalu ada pengkajian ulang terhadap data yang perawat lakukan. Data yang dikumpulkan pada saat pengkajian betul-betul data yang diperoleh dari alat yang terukur dan diperoleh oleh perawat yang terampil dan ahli. Masalah keperawatan harus dikenali perawat dari batasan karakteristiknya masingmasing. Kemudian perawat harus menegakkan sebuah diagnosa keperawatan jika telah ditemukan batasan karakteristiknya.

Berdasarkan pendapat dari beberapa ahli tentang tahapan dalam proses keperawatan, tahapan dimulai dengan tahap pengkajian, tahap diagnosa keperawatan, tahap perencanaan, tahap pelaksanaan serta tahap evaluasi.

1. Pengkajian, yaitu mengumpulkan data, mengelompokan/mengatur data, validasi data, dan mendokumentasikan data.

2. Diagonasa kesehatan, resiko, kekuatan, yaitu menganalisa data, mengidentifikasi masalasah, merumuskan pernyataan, dan diagnosa keperawatan.

3. Perencanaan diharapkan, yaitu memprioritaskan masalah, merumuskan tujuan/hasil, memilih intervensi keperawatan, dan menulis rencana keperawatan.

4. Implemetasi kebutuhan pasien, yaitu mengkaji kembali pasien, menentukan bantuan dan mengimplementasikan rencana, tindakan keperawatan, melakukan supervisi keperawatan, dan mendokumentasikan tindakan keperawatan. 
5. Evaluasi hasil, yaitu mengumpulkan data yang berhubungan dengan hasil, membandingkan data dengan menghubungkan tindakan keperawatan dengan tujuan/hasil, menarik kesimpulan tentang status masalah, serta melanjutkan, memodifiksi atau mengakhiri rencana asuhan keperawatan.

Dalam melaksanakan proses keperawatan diperlukan pengetahuan yang cukup untuk meningkatkan mutu asuhan keperawatan. Pengetahuan merupakan domain yang sangat penting dalam membentuk tindakan seseorang (over behavior) pada kenyataannya. Perilaku yang didadari pengetahuan akan lebih baik dari pada perilaku yang tidak didasari oleh pengetahuan.

Faktor-faktor yang mempengaruhi pengetahuan seseorang yaitu pendidikan, berarti bimbingan yang diberikan seseorang kepada orang lain terhadap suatu hal agar mereka dapat memahami. Tidak dapat dipungkiri bahwa makin tinggi pendidikan seseorang semakin mudah pula mereka menerima informasi, dan pada akhirnya makin banyak pula pengetahuan yang dimilikinya. Sebaliknya, jika seseorang tingkat pendidikannya rendah, akan menghambat perkembangan sikap seseorang terhadap penerimaan informasi dan nilai-nilai baru diperkenalkan.
Adanya pengetahuan yang cukup dalam melaksanakan proses keperawatan akan membuat perawat mempunyai rasa percaya diri. Perawat akan lebih percaya diri melaksanakan tindakan asuhan keperawatan, karena semua perencanaan disusun dengan baik berdasarkan kepada diagnosa keperawatan yang ditunjang oleh data-data yang tepat dan akurat. Proses keperawatan yang tepat akan memberikan peningkatan kualitas asuhan keperawatan. Asuhan keperawatan yang optimal, akan mempercepat proses kesembuhan klien. Hal ini tentunya akan memberikan kepuasan bagi klien dan perawat sendiri. Proses keperawatan yang diterapkan akan membantu pengembangan profesionalisme perawat dan proses keperawatan yang terdokumentasi dengan baik, akan memudahkan bagi staf lainnya dalam melaksanakan asuhan keperawatan.

Bagi klien, proses keperawatan yang tepat berdasarkan pengetahuan dan pengalaman perawat yang cukup akan meningkatkan kerjasama klien dalam pelaksanaan tindakan keperawatan, dapat menjamin klien akan mendapatkan asuhan keperawatan yang berkesinambungan, dapat mencegah terjadinya duplikasi tindakan dan kekurangan tindakan, dan proses keperawatan akan membuat klien mendapatkan kualitas pelayanan asuhan keperawatan yang prima. 
Bagi rumah sakit ataupun puskesmas, proses keperawatan tersebut akan memberikan kepuasan klien, sehingga akan membuat klien menjadi pelanggan tetap rumah sakit atau puskesmas dimana perawat bekerja. Dengan sendirinya klien akan menceritakan kepuasannya mendapat pelayanan asuhan keperawatan yang perawat lakukan, sehingga orang lain berkeinginan untuk mendapatkan pelayanan tersebut. Meningkatnya jumlah klien yang menjadi pelanggan, akan meningkatkan pendapatan rumah sakit atau puskesmas tempat perawat bekerja.

\section{Penutup}

Kesimpulan dan Saran

Proses keperawatan adalah suatu cara atau metode yang sistematis dalam memberikan asuhan keperawatan yang dilakukan oleh perawat dan bekerjasama dengan pasien untuk mengidentifikasi masalah keperawatan dengan melakukan pengkajian, menentukan diagnosa, merencanakan tindakan yang akan dilakukan, melaksanakan tindakan serta mengevaluasi hasil asuhan keperawatan yang telah diberikan.

Dalam melaksanakan proses keperawatan diperlukan pengetahuan yang cukup untuk meningkatkan mutu asuhan keperawatan karena pengetahuan merupakan domain yang sangat penting dalam membentuk tindakan seseorang (over behavior) pada kenyataannya. Perilaku yang didadari pengetahuan akan lebih baik dari pada perilaku yang tidak didasari oleh pengetahuan. Maka dari itu, pengetahuan perawat sangatlah penting dalam melaksanakan proses keperawatan untuk mengarahkan dan memfokuskan dalam upaya meningkatkan mutu asuhan keperawatan.

\section{Daftar Pustaka}

Achmadi, L. D. L., Pondaag, L., \& Babakal, A. (2015). Gambaran tingkat pengetahuan perawat dalam penerapan standar asuhan keperawatan di ruangan rawat inap interna RSUD Datoe Bhinangkang. E-Journal Keperawatan (e-Kp), 3(3).

Agustina, V., Mardiono, \& Ibrahim, D. A. F. (2016). Hubungan tingkat pengetahuan dengan sikap perawat dalam pelaksanaan ronde keperawatan di ruang Aster dan ICCU RSUD dr. Doris Sylvanus. Dinamika Kesehatan, 7(1), 236-240.

Budiono, S. B. P. (2015). Konsep dasar keperawatan. Jakarta: Bumi Medika.

Buheli, K. (2012). Faktor yang mempengaruhi kinerja perawat dalam penerapan proses keperawatan di RSUD Toto Kabupaten Bone Bolango. Jurnal Sainstek, 6(5). 
Dermawan, D. (2012). Proses keperawatan: Penerapan konsep \& kerangka kerja. Yogyakarta: Gosyen.

Koerniawan, D., Daeli, N. E., \& Srimiyati. (2020). Aplikasi standar proses keperawatan: Diagnosa, outcome, dan intervensi pada asuhan keperawatan. Jurnal Keperawatan Silampari, 3(2), 739-751.

Meidianta, A. C. \& Milkhatun. (2020). Hubungan antara pelatihan proses keperawatan dengan pengetahuan perawat tentang penerapan standar diagnosis keperawatan indonesia di RSUD Samarinda. Borneo Student Research, 1(2), 647-651.

Simamora, R. H. (2019). Development of Guidelines for Applying appropriate Patient Identification to Achieve Patient Safety Goal INC 2019 12th International Nursing Conference. $2019.10455 \quad$ - $455 \quad$ (1 pages) UCI(KEPA) : I410-ECN-0101-2019512-001224337.

Simamora. R. H. (2008). The correlation of ward chief's giving direction and command and the performance of onduty nurses at Jember dr. Subandi general hospital inpatient wards. Jurnal Administrasi dan Kebijakan Kesehatan,

(https://fkm.unair.ac.id/jurnaladministr).

Sinlaeloe, R., Berkanis, A. T., \& Barimbing, M. A. (2020). Hubungan pengetahuan dan sikap perawat terhadap kelengkapan pendokumentasian asuhan keperawatan di ruang rawat inap RSUD Prof. Dr. W. Z. Johannes Kupang. CHMK Nursing Scientific Journal, 4(3), 268-277.

Sugiyati, S. (2015). Hubungan pengetahuan perawat dalam dokumentasi keperawatan dengan pelaksanaannya di rawat inap RSI Kendal. Jurnal Keperawatan, 8(2), 109-125.

Wiludjeng, R. (2017). Hubungan motivasi kerja dengan pelaksanaan pendokumetasian proses keperawatan di Puskesmas Riam Durian. Jurnal Borneo Cendekia, 1(1), 44-48. 